TEME, г. XLI, бр. 1, јануар-март 2017, стр. 227-241

Прегледни рад

DOI: $10.22190 /$ TEME1701227M

Примљено: 14. 01. 2016.

UDK 316.624-053.6:796.332

Ревидирана верзија: 25. 03. 2016.

Одобрено за штампу: 17. 01. 2017.

\title{
ДЕТЕРМИНАНТНА ОБЕЛЕЖЈА АДОЛЕСЦЕНТНОГ ЧЛАНА НАВИЈАЧКЕ ГРУПЕ
}

\author{
Саша Милојевић*, Саша Мијалковић, Бојан Јанковић \\ Криминалистичко-полицијска академија, Београд, Србија \\ *sasa.milojevic@kpa.edu.rs
}

\begin{abstract}
Апстракт
Радом се жели одговорити на питање да ли постоје одређујуће заједничке карактеристике адолесцената који се прикључују навијачким групама. Основа за то биће резултати статистичке анализе података прикупљених истраживањем у периоду 2012-2014. године. Узорак је обухватио ученике са територије Републике Србије из 12 градова који су имали прволигашке фудбалске клубове у сезони одиграној 2012/2013. године. Анкетирано је 3662 ученика. Анализа прикупљених података показала је да се млади члан навијачке групе може описати као мушкарац који учествује у сукобима због погрешно усмерених навијачких страсти, који злоупотребљава наркотике и против којег је полиција подносила кривичне пријаве након привођења због навијачког насиља. Он сматра да је довољно упознат са проблемом навијачког насиља и његовим последицама и не жели да се додатно едукује, али и препознаје расистичке испаде када се десе на спортским борилиштима.
\end{abstract}

Кључне речи: хулиганизам, адолесценти, навијачке групе, обележја.

\section{DETERMINANT CHARACTERISTICS OF AN ADOLESCENT MEMBER OF A FAN GROUP}

\begin{abstract}
This paper aims to answer the question of whether there are common characteristics of adolescents who join club fan groups on the basis of the data collected during the research conducted from 2012 to 2014 on the sample comprising of secondary school students from the territory of the Republic of Serbia from 12 cities that had first division football clubs in the 2012/2013 season. 3662 students were surveyed. The analysis of the collected data showed that a young member of a fan group could be described as a male adolescent who participated in clashes because of football, who was abused illicit drugs and who was apprehended by the police and against whom criminal charges for violence in football stadiums were filed.
\end{abstract}

Key words: hooliganism, adolescents, fan groups, characteristics. 
УВОД

Хулиганско понашање дела навијача на фудбалским утакмицама представља вишедеценијски проблем са којим се суочава велики број земаља света, укључујући и Србију. Насилничко понашање често се повезује са навијачким групама, које су главни учесници хулиганизма на стадионима. У последњој деценији уочена је тенденциjа да се навијачким групама све више прикључују адолесценти (Janković, 2010; Milojević \& Janković, 2012; Милошевић и Милашиновић, 2011; Otašević, 2010, 2012; Живковић, Стаменковић и Марковић, 2013). Због тога је сврсисходно истражити која обележја карактеришу адолесценте који се прикључују навијачким групама.

\section{ТЕОРИЈСКИ ОКВИР}

Значајно обележје навијачког насиља и хулиганског деловања навијачких група јесте да је оно учесталије у већим урбаним срединама. Наиме, у истраживању спроведеном у Београду, на основу анализе званичних полицијских података, утврђено је да је у главном граду Републике Србије евидентирано 2525 чланова навијачких група, од којих су 875 насилници, а 1389 потенцијални насилници, те да у Београду има највише чланова навијачких група. При томе, нешто мање од половине чине лица млађа од 18 година (Оташевић, 2010). Исто тако, у истраживању спроведеном у Великој Британији наводи се да су навијачке групе у већим градским срединама организованије (The Premier League, 2008).

Родна структура навијачких група била је предмет више научних студија. У истраживању криминалитета код адолесцената на територији града Београда у периоду 1998-2006. године, Симеуновић Патић (2009) наводи да је насилничко понашање на спортској приредби једно од кривичних дела код којих су се, као учиниоци, у узорку појавили искључиво припадници мушког пола. Резултати истраживања у Аустралији указују на то да су у навијачким групама мушкарци у огромној већини и да они често чине сексуалне деликте према малобројним женама у групи (Roumen, 2008). Статистички подаци из Велике Британије говоре да мушкарци чине $85 \%$ популације навијачких група (The Premier League, 2008).

Структура породице и односи у њој представљају обележје које утиче на учешће појединца у навијачкој групи и такође су предмет неких истраживања. Индикативан је резултат да половина извршилаца насилничког понашања на спортским приредбама у Београду потиче из породица у којима су односи лоши, као и да отац сваког четвртог адолесцента из те категорије прекомерно конзумира алкохол (Симеуновић-Патић, 2009). Исто тако, истраживање навијачких група у Великој Британији показало је да су чланови навијачких гру- 
па већином неожењени мушкарци или адолесценти који живе са једним родитељем (The Premier League, 2008). Такође, социолошко истраживање које је спроведено у Ирану указало је на значајну корелацију између дисфункционалности породице и хулиганизма на фудбалским утакмицама (Mostahfezian \& Sarrami, 2012).

Материјално стање, као фактор који може да утиче на прикључивање адолесцента навијачкој групи, такође је тема одређеног броја радова. Истраживање у Великој Британији показало је да чланови навијачких група већином долазе из горње средње класе (42\%) и доње средње класе (32\%) (The Premier League, 2008). Такође, нека истраживања указују на то да узроцима екстремног понашања навијача треба додати и друштвену кризу као погодан оквир за хулиганизам - што је криза већа, насиље и хулиганизам су израженији (Мисић, 2010).

Важно обележје чланова навијачких група јесте њихова спремност да уђу у сукобе због навијачких страсти. Истраживања у Ирану указују на то да постоји значајна корелација између претходних учешћа у сукобима (било какве врсте) и хулиганизма на фудбалским утакмицама (Mostahfezian \& Sarrami, 2012). Млади у групи су агресивнији и спремнији да изазову нереде и насиље него њихови вршњаци који нису уједињени (Earle, 2011). Истраживања у Србији (Đorić, 2012; Мисић, 2010) указују на пораст насиља, на адолесценте као основну социјалну основу хулиганизма, на континуирано насилничко понашање, као и на то да је овај вид насиља карактеристичан за фудбалске утакмице.

На повезаност хулиганизма навијачких група са конзумацијом алкохола такође указује низ објављених истраживања. У једном од њих, које је спроведено у Београду, утврђено је да је вршење кривичног дела у стању алкохолисаности било посебно карактеристично за учиниоце насилничког понашања на спортској приредби (Симеуновић-Патић, 2009). Аришита (Arishita, 2010) указује на то да насиље на стадионима често има подлогу у ситуационим факторима као што су дејство алкохола и утицај психологије масе који произлази из чланства у навијачкој групи. Иако је конзумација алкохола културолошка одлика, тј. одлика одређеног менталитета, приметно је да је прекомерна конзумација алкохола карактеристична и за навијачке групе. Под утицајем спортских резултата и алкохола, чланови тих група бурно емотивно реагују, што често води ка насиљу и хулиганизму (Varela, 2014).

Повезаност хулиганизма са злоупотребом наркотика такође је једно од значајних обележја чланова навијачких група. На пример, Милошевић и Милашиновић (2011) као једну од специфичности навијачког насиља истичу и прекомерно конзумирање опојних средстава. Истраживање спроведено у Ирану (Mostahfezian \& Sarrami, 2012) такође указује на значајну корелацију између злоупотребе наркотика и хулиганизма на фудбалским утакмицама. 
Једно од значајнијих обележја чланова навијачких група јесте њихов однос према полицији и њеном раду на сузбијању фудбалског хулиганизма. Истраживања су показала да полицијске организације прелазе на проактивне тактике супротстављања хулиганизму, које су засноване пре свега на познавању психологије масе (Stott, Adang, Livingstone, \& Schreiber, 2008) и комуникацији између навијача и полиције (Наu, 2006). Наиме, ранија искуства су показала да, у појединим ситуацијама, насиље може бити изазвано агресивним наступом полиције (Spaaij, 2005). Да је то тако потврђује и истраживање из Beлике Британије чији резултати говоре да су честа агресивна поступања полиције у покушајима сузбијања насиља на утакмицама узроковала веома негативан став чланова навијачких група према полицијским снагама (Essays, n. d.).

Значајан део истраживања о навијачком хулиганизму бавио се анализом репресивних полицијских мера, па се и привођење од стране полиције, те прекршајно и кривично процесуирање могу издвојити као обележје чланова навијачких група. На пример, у радовима који се баве поступањем полиције према насилним навијачима дат је преглед броја приведених изгредника, који указује на повезаност између привођења адолесцената на стадионима и њиховог чланства у навијачким групама (Adang \& Brown, 2008; Марковић, 2016; Milojević \& Janković, 2011; Оташевић, Вла и Исаковић, 2011). Истраживање у Србији показује да је против 30 вођа навијачких група поднето укупно 279 кривичних пријава, што значи да је један вођа навијачке групе извршио у просеку 9,3 кривича дела, и то у периоду од 8,52 године (Милојевић, Симоновић, Јанковић, Оташевић и Турањанин, 2014). До сличног закључка дошла је и друга група аутора, која у свом раду истиче да спорт, с једне стране, подстиче везивање различитих група, нација и култура, али се, с друге стране, у њему и у вези с њим често појављују насиље и вршење кривичних дела и прекршаја (Милашиновић, Милојевић и Крстић-Мистриџиловић, 2014).

У последњих неколико година део радова из ове области бави се проблемом расизма на фудбалским утакмицама (Bošković, 2006; Мијалковић, 2015; Мисић, 2010; Оташевић, 2010). На пример, Бошковић (2006) указује на то да је расизам у српском фудбалу велики проблем. Једно истраживање расизма у британском фудбалу у којем су путем онлајн анкете анализирани одговори 2500 навијача указало је да велики број испитаника (између 50 и $83 \%$, у зависности од године) сматра да расизам на британским стадионима и даље постоји (Cleland \& Cashmore, 2013).

Ниво упознатости са проблемом навијачког насиља и његовим последицама по друштво такође је обележје које значајно одређује насилнике на фудбалским стадионима. Да је то тако показују и претходна истраживања по којима је смањење хулиганског понашања 
на утакмицама повезано с тим колико су посетиоци стадиона упознати с проблемом насиља у спорту и последицама које оно носи (Savković \& Đorđević, 2010). Када су се у Великој Британији, захваљујући одређеним превентивним програмима, навијачи боље упознали са проблемом насиља на стадионима и његовим последицама, број младих који се идентификују са фудбалским хулиганизмом приметно је смањен (Essays, n. d.).

Пристајање на подучавање о проблему навијачког насиља и разумевање њеног значаја још једно је битно обележје које одређује адолесценте из навијачких група. Ранији налази указују на то да превентивни едукативни програми могу бити корисни само ако их циљна популација прихвата (Savković \& Đorđević, 2010). Један број аутора износи уверење да посебне превентивне програме треба прилагодити младим навијачима (Đorić, 2012; Janković, 2010; Мисић, 2010), јер на старије особе (већ формиране навијаче) они не могу да се примене. Нешто слично у свом истраживању тврди и Радуловић (2010), који каже да се рад са навијачима мора усмерити ка млађој популацији јер је превенција адолесцентске делинквенције кључни део укупне превенције криминалитета у друштву.

Из претходних разматрања уочљиво је да се из резултата ранијих истраживања могу издвојити поједина обележја која су карактеристична за адолесценте у навијачким групама. На основу теоријског оквира поменутих истраживања, у раду се разрађује претпоставка да постоји комбинација обележја која у међусобној интеракцији дају јединствен статистички значајан допринос опису адолесцента који је припадник навијачке групе.

\section{МЕТОД И УЗОРАК}

Да би се дошло до података о обележјима адолесцената који се прикључују навијачким групама, сачињен је анкетни упитник са јасно и недвосмислено формулисаним питањима. Анкетирање испитаника било је анонимно. У раду су представљени резултати прикупљени помоћу упитника ${ }^{1}$ са 13 питања ${ }^{2}$, на која су понуђени затворени одговори бинарног типа.

\footnotetext{
${ }^{1}$ Питања су била: (1) Који је Ваш пол?; (2) Да ли живите са оба родитеља?; (3) Да ли су оба родитеља запослена и редовно примају лични доходак?; (4) Да ли сте учествовали у навијачким сукобима?; (5) Да ли конзумирате алкохол?; (6) Да ли користите наркотике?; (7) Какав је Ваш генерални став према полицији?; (8) Да ли Вас је полиција приводила због учешћа у навијачком хулиганизму?; (9) Да ли је против Вас подношена прекршајна пријава због учешћа у навијачком хулиганизму?; (10) Да ли је против Вас подношена кривична пријава због учешћа у навијачком хулиганизму?; (11) Да ли на спортским манифеста-
} 
Прикупљени подаци обрађени су помоћу: (1) процедура које су приказале дескриптивне параметре (фреквенцију и проценат); (2) регресионих техника (бинарна логистичка регресија) за испитивање ваљаности модела обележја којима се описује адолесцентни припадник навијачке групе (Милошевић и Милојевић, 2001).

Подаци о учешћу младих у насиљу на фудбалским утакмицама прикупљани су на узорку који је обухватио ученике узраста од 14 до 19 година са територије Републике Србије. Испитаници су били из 12 градова ${ }^{3}$ који су имали прволигашке фудбалске клубове у сезони 2012/2013. године ${ }^{4}$, из по две школе које су најближе фудбалском стадиону ${ }^{5}$. Анкетирани су ученици све четири генерације, и то по два одељења из сваке (одељење са најмање и одељење са највише изостанака). На основу тих критеријума анкетирано је 3662 ученика. Ако се узме у обзир да је, по подацима Републичког завода за статистику, на почетку школске 2012/2013. године у Србији било 280.422 ученика наведеног узраста, узорак је обухватио 1,3\% анализиране популације (Statistical Office of the Republic of Serbia, 2013). Имајући у виду да се ради о стратификованом узорку, његова величина у потпуности представља циљану популацију ученика старости од 14 до 19 година са нивоом поузданости 95\% и интервалом поузданости 0,63 , при чему је стопа пристајања испитаника на давање одговора била 95,3\%.

Две трећине испитаника $(66,4 \%)$ чинили су ученици из великих градова. ${ }^{6}$ Већи број испитаника $(55,4 \%)$ био је мушког пола. У

цијама у Србији има расистичких испада?; (12) Да ли сте довољно упознати са проблемом навијачког насиља, хулиганизмом на спортским манифестацијама и последицама таквог понашања навијача?; (13) Да ли бисте желели да се додатно едукујете о проблему навијачког насиља, хулиганизму на спортским манифестацијама и последицама таквог понашања навијача?

${ }^{2}$ Податак о граду у којем је вршено анкетирање добијен је од анкетара, а затим је на основу званичних статистичких података (Statistical Office of the Republic of Serbia, 2013) о броју становника по градовима преведен у бинарни облик велики и мали град.

${ }^{3}$ То су: Суботица, Пећинци, Кула, Нови Сад, Београд, Смедерево, Крагујевац, Јагодина, Ниш, Ужице, Ивањица и Нови Пазар.

${ }^{4}$ Мисли се на: ФК Црвена звезда, ФК Партизан, ФК Рад, ОФК Београд, ФК БСК, ФК Војводина, ФК Доњи Срем, ФК Хајдук, ФК Спартак, ФК Јагодина, ФК Раднички, ФК Смедерево, ФК Јавор, ФК Слобода, ФК Нови Пазар и ФК Раднички 1923. ${ }^{5}$ Том методологијом стратификације требало је да се одаберу 32 средње школе (16 клубова, по 2 школе). Међутим, испоставило се да Пећинци имају само једну средњу школу, а да су XII београдска гимназија и IV београдска гимназија истовремено најближе стадионима ФК Црвена звезда, ФК Партизан, ФК Рад, док су Пета београдска гимназија и Средња техничка ПТТ школа истовремено најближе стадионима ОФК Београд и ФК БСК.

${ }^{6}$ Под великим градом подразумевало се да град у коме испитаник живи има више од 100.000 становника. 
комплетној породици ${ }^{7}$ живи $82,7 \%$ испитаника. Да им је материјална ситуација повољна $^{8}$ изјаснило се $53,2 \%$ њих. Четвртина испитаника $(25,3 \%)$ учествовала је у некој врсти сукоба због спорта (18,7\% мушкараца и 6,5\% девојака). Велики број њих конзумира алкохол $(69,0 \%)$, а значајан број злоупотребљава наркотике $(9,6 \%)$. Неповољан став према полицији има $49,8 \%$ испитаника. Због насиља у вези са спортом привођено је 5,6\%; против 3,8\% полиција је поднела прекршајне пријаве, а против $3,2 \%$ и кривичне пријаве. Да у Србији постоје проблеми са расизмом на фудбалским утакмицама сматра $67,8 \%$ испитаника. С проблемом насиља и хулиганизма на фудбалским утакмицама, као и њиховим последицама, упознато је 24,6\% њих, а 57,8\% сматра да би им едукација о томе користила. Чланови организованих навијачких група чинили су $14,7 \%$ одабраног узорка (12,4\% мушкараца и 2,3\% девојака).

\section{РЕЗУЛТАТИ И ДИСКУСИЈА}

Расподела одговора анкетираних ученика на питања која се односе на анализирана обележја из теоријског модела, када се узорак подели на чланове навијачких група и оне који то нису, приказана је у Табели 1.

Резултати из Табеле 1 указују на то да у мањим градовима адолесценти чешће постају чланови навијачких група $(38,2 \%)$. Такође, мушкарци се много чешће прикључују навијачким групама него девојке. Од испитаника који су се изјаснили да су чланови навијачких група, 84,4\% њих је мушког пола. Као што се и очекивало, чланови навијачких група су много чешће учествовали у некој врсти сукоба због спорта. Чак $67,7 \%$ испитаника који тврде да су чланови навијачких група изјаснили су се да су учествовали у неком облику сукоба. Такође, они чешће конзумирају алкохол од других вршњака чак $74,2 \%$ њих то чини. Адолесценти из навијачких група знатно чешће злоупотребљавају и наркотике - чак $18,7 \%$ њих тврди да користи наркотике, што је преко два пута већи проценат у односу на остатак анкетиране популације. Чланови навијачких група много чешће имају неповољан став према полицији - чак $70,8 \%$. Њих је полиција такође много чешће приводила због насиља на фудбалским утакмицама - 23,2\% приведено је због хулиганизма. Против чланова навијачких група чешће су подношене и прекршајне $(15,0 \%)$, односно кривичне пријаве $(13,7 \%)$, а ти проценти далеко су мањи у остатку анке-

\footnotetext{
${ }^{7}$ Под комплетном породицом подразумевало се да испитаник живи са оба родитеља.

${ }^{8}$ Под повољном материјалном ситуацијом подразумевало се да оба родитеља раде и редовно примају личне дохотке.
} 
тираних. Интересантно је да адолесценти из навијачких група много чешће сматрају да се на фудбалским утакмицама дешавају расистички испади - чак $87,7 \%$ њих има такво мишљење. Исто тако, они се много чешће изјашњавају да су упознати са проблемом хулиганизма на стадионима - 36\% њих. Већина анкетираних чланова навијачких група $(59,3 \%)$ сматра да би детаљније информисање о проблему насиља на стадионима било бескорисно и да га не треба спроводити.

Табела 1. Расподела обележја испитаника при њиховој подели на чланове навијачких група и оне који то нису

Table 1. The distribution characteristics of the subjects when they be divided into those who are members of fan groups and those who are not

\begin{tabular}{|c|c|c|c|c|c|c|}
\hline \multirow{3}{*}{ Питање (обележје) } & \multicolumn{2}{|c|}{$\begin{array}{c}\text { Чланови навијачких } \\
\text { група } \\
\end{array}$} & \multicolumn{4}{|c|}{ Остали испитаници } \\
\hline & Одговор а & Одговор б" & \multicolumn{2}{|c|}{ Одговор а" } & \multicolumn{2}{|c|}{ Одговор б" } \\
\hline & $\begin{array}{c}\text { Број } \\
\text { одгово \% } \\
\text { ра (N) }\end{array}$ & $\begin{array}{l}\text { Број } \\
\text { одговора \% } \\
\text { (N) }\end{array}$ & $\begin{array}{c}\text { Број } \\
\text { одговора } \\
\text { (N) }\end{array}$ & $\%$ & $\begin{array}{c}\text { Број } \\
\text { одговора } \\
(\mathrm{N})\end{array}$ & $\%$ \\
\hline 1. Величина града & 33361,8 & 20638,2 & 2.100 & 67,2 & 1.023 & 32,8 \\
\hline 2. Пол & 8415,6 & 45484,4 & 1.548 & 49,6 & 1.570 & 50,4 \\
\hline $\begin{array}{l}\text { 3. Комплетност } \\
\text { породице }\end{array}$ & 43881,4 & 10018,6 & 2.585 & 83,0 & 531 & 17,0 \\
\hline $\begin{array}{l}\text { 4. Материјална } \\
\text { ситуација }\end{array}$ & 30356,5 & 23343,5 & 1.647 & 53,1 & 1.457 & 46,9 \\
\hline 5. Учешће у сукобу & 35667,7 & 17432,3 & 561 & 18,0 & 2.562 & 82,0 \\
\hline $\begin{array}{l}\text { 6. Конзумација } \\
\text { алкохола }\end{array}$ & 40074,2 & 13925,8 & 2.125 & 68,0 & 998 & 32,0 \\
\hline $\begin{array}{l}\text { 7. Злоупотреба } \\
\text { наркотика }\end{array}$ & 10118,7 & 43881,3 & 251 & 8,0 & 2.872 & 92,0 \\
\hline $\begin{array}{l}\text { 8. Став према } \\
\text { полицији }\end{array}$ & 9729,2 & 23570,8 & 911 & 54,3 & 766 & 45,7 \\
\hline $\begin{array}{l}\text { 9. Полицијско } \\
\text { привођење }\end{array}$ & 12123,2 & 40176,8 & 81 & 2,6 & 2.999 & 97,4 \\
\hline $\begin{array}{l}\text { 10. Прекршајна } \\
\text { пријава }\end{array}$ & 7915,0 & 44785,0 & 57 & 1,8 & 3.029 & 98,2 \\
\hline $\begin{array}{l}\text { 11. Кривична } \\
\text { пријава }\end{array}$ & 7113,7 & 44886,3 & 44 & 1,4 & 3.030 & 98,6 \\
\hline $\begin{array}{l}\text { 12. Став да има } \\
\text { расизма у спорту }\end{array}$ & 46387,7 & 6512,3 & 1.812 & 64,1 & 1.013 & 35,9 \\
\hline $\begin{array}{l}\text { 13. Познавање } \\
\text { проблема } \\
\text { хулиганизма }\end{array}$ & 18636,0 & 33064,0 & 684 & 22,6 & 2.336 & 77,4 \\
\hline $\begin{array}{l}\text { 14. Корисност } \\
\text { едукације о } \\
\text { хулиганизму }\end{array}$ & 21540,7 & 31359,3 & 1.851 & 60,7 & 1.197 & 39,3 \\
\hline
\end{tabular}

* Одговори на питања били су: (1) а) велики град, б) мањи град; (2) а) женски, б) мушки; (3) а) да, б) не; (4) а) да, б) не; (5) а) да, б) не; (6) а) да, б) не; (7) а) да, б) не; (8) а) позитиван, б) негативан; (9) а) да, б) не; (10) а) да, б) не; (11) а) да, б) не; (12) а) да, б) не; (13) а) да, б) не; (14) а) да, б) не. 
Од 14 претходно разматраних обележја формиран је модел за опис адолесцентног члана навијачке групе. На том моделу је директном бинарном логистичком регресијом провераван степен интеракције датих обележја у претпостављеном опису. Резултати регресионе анализе приказани су у Табели 2.

Табела 2. Резултати регресионе анализе

Table 2. Results of regression analysis

\begin{tabular}{|c|c|c|c|c|c|c|c|}
\hline \multirow[t]{2}{*}{ Обележје (предиктор) } & \multirow[t]{2}{*}{ B } & \multirow[t]{2}{*}{ S.E. } & \multirow[t]{2}{*}{ Wald } & \multirow[t]{2}{*}{ Sig. } & \multirow[t]{2}{*}{$\operatorname{Exp}(B)$} & \multicolumn{2}{|c|}{$\begin{array}{c}95 \% \text { C.I. } \\
\text { за } \operatorname{EXP(B)} \\
\end{array}$} \\
\hline & & & & & & Lower & Upper \\
\hline Величина града & $-0,09$ & 0,18 & 0,25 & 0,624 & 0,92 & 0,65 & 1,29 \\
\hline Пол $^{* *}$ & 2,16 & 0,22 & 95,94 & 0,000 & 8,64 & 5,61 & 13,31 \\
\hline Комплетност породице & $-0,06$ & 0,22 & 0,07 & 0,801 & 0,94 & 0,61 & 1,47 \\
\hline Материјална ситуација & $-0,14$ & 0,17 & 0,68 & 0,417 & 0,87 & 0,62 & 1,22 \\
\hline Учешће у сукобу ${ }^{* *}$ & 2,58 & 0,21 & 158,93 & 0,000 & 13,23 & 8,86 & 19,77 \\
\hline Конзумација алкохола & $-0,22$ & 0,20 & 1,21 & 0,277 & 0,81 & 0,55 & 1,18 \\
\hline Злоупотреба наркотика ** & 0,59 & 0,27 & 4,65 & 0,002 & 0,56 & 0,33 & 0,95 \\
\hline Став према полицији & 0,30 & 0,18 & 2,82 & 0,091 & 1,35 & 0,95 & 1,92 \\
\hline Полицијско привођење & 0,88 & 0,35 & 6,39 & 0,001 & 2,42 & 1,22 & 4,81 \\
\hline Прекршајна пријава & $-0,59$ & 0,53 & 1,23 & 0,272 & 0,55 & 0,20 & 1,57 \\
\hline Кривична пријава ${ }^{* *}$ & 1,45 & 0,55 & 7,02 & 0,001 & 4,27 & 1,46 & 12,50 \\
\hline $\begin{array}{l}\text { Став да има расизма у } \\
\text { спорту }\end{array}$ & 0,57 & 0,25 & 4,35 & 0,002 & 0,55 & 0,32 & 0,96 \\
\hline $\begin{array}{l}\text { Познавање проблема } \\
\text { хулиганизма }\end{array}$ & 0,58 & 0,18 & 10,10 & 0,000 & 1,79 & 1,25 & 2,55 \\
\hline $\begin{array}{l}\text { Корисност едукације о } \\
\text { хулиганизма }\end{array}$ & 0,81 & 0,17 & 22,13 & 0,001 & 2,25 & 1,61 & 3,16 \\
\hline
\end{tabular}

\footnotetext{
* За све предикторе број степени слободе $\mathrm{df}=1$

** Статистички значајно на нивоу р $<0,003$. Ниво значајности је

Бонферонијевом корекцијом снижен због величине узорка ради смањења вероватноће да се учини грешка прве врсте.
}

Цео модел помоћу ког је провераван утицај наведених 14 обележја на вероватноћу да су адолесценти чланови навијачких група био је статистички значајан $\left(\chi^{2}(14, \mathrm{n}=3662)=636,21, \mathrm{p}=0,00\right)$. То показује да модел разликује испитанике који су чланови навијачких група од оних који то нису. Ону целину објашњава између $31,1 \%\left(\mathrm{r}^{2}\right.$ Koksa and Snela) и 51,5\% ( $\mathrm{r}^{2}$ Nagelkerkea) варијансе у вероватноћи да ће испитаник бити члан навијачке групе и тачно класификује чак $90 \%$ случајева. Као што је приказано у Табели 2, чак осам предиктора дало је јединствен статистички значајан допринос моделу (пол, 
сукоби због спорта, злоупотреба наркотика, привођење због насиља на спортским приредбама, поднесене кривичне пријаве, став да на утакмицама има расизма, испитаник је упознат са проблемом хулиганизма и испитаник сматра да није корисно да буде едукован о проблему хулиганизма).

Дакле, адолесценти мушког пола су преко осам и по пута чешће чланови навијачких група $(\operatorname{Exp}(B)=8,64)$, што је у складу са ранијим налазима (The Premier League, 2008; Roumen, 2008; Симеуновић-Патић, 2009). Они који су учествовали у сукобу због спорта, преко 13 пута чешће су у саставу навијачких група $(\operatorname{Exp}(B)=13,23)$, што је такође у складу са резултатима ранијих истраживања (Đorić, 2012; Earle, 2011; Мисић, 2010; Mostahfezian \& Sarrami, 2012). Припадници популације адолесцената који не злоупотребљавају наркотике 0,56 пута ређе су чланови навијачких група, што потврђује резултате ранијих студија (Милошевић и Милашиновић, 2011; Mostahfezian \& Sarrami, 2012). Адолесценти који су привођени због сукоба на стадионима преко два пута чешће су у навијачким групама $(\operatorname{Exp}(B)=2,42)$, што потврђује налазе ранијих истраживања (Adang \& Brown, 2008; Марковић, 2016; Milojević \& Janković, 2011; Оташевић, Вла и Исаковић, 2011). Они против којих су подношене кривичне пријаве преко четири пута чешће постају чланови навијачких група $(\operatorname{Exp}(B)=4,27)$, што такође потврђује резултате ранијих студија (Милашиновић и сарадници, 2014; Милојевић и сарадници, 2014; Симеуновић-Патић, 2009). Испитаници који сматрају да на стадионима нема расизма су 0,55 пута ређе у навијачким групама, што указује на то да чланови навијачких група препознају хулиганске испаде који имају расистичка обележја, а то је такође у складу са ранијим налазима (Bošković, 2006; Cleland \& Cashmore, 2013; Мијалковић, 2015; Мисић, 2010; Оташевић, 2010). Адолесценти који су упознати са проблемом насиља на фудбалским утакмицама 1,79 пута чешће су чланови навијачких група, вероватно због тога што су досадашњи превентивни програми били усмерени према члановима навијачких група, па су они, поред тога што су актери и сведоци насиља, и боље упознати са тим проблемом - то такође потврђује налазе ранијих истраживања (Essays, n. d.; Savković \& Đorđević, 2010). На крају, они адолесценти који сматрају да није потребно спроводити додатну едукацију о проблему насиља на утакмицама преко два пута чешће се прикључују организованим навијачким групама $(\operatorname{Exp}(\mathrm{B})=$ 2,25 ), што је у складу са резултатима ранијих студија (Đorić, 2012; Janković, 2010; Мисић, 2010; Radulović, 2010; Savković \& Đorđević, 2010).

За поједина обележја из теоријског оквира прикупљени подаци нису указали на то да њихова међусобна интеракција даје јединствен статистички значајан допринос опису адолесцента као припадника навијачке групе иако су на то указивала ранија истраживања 
(Arishita, 2010; Essays, n.d; Наu, 2006; Милашиновић и сарадници, 2014; Мисић, 2010; Mostahfezian \& Sarrami, 2012; Оташевић, 2010; The Premier League, 2008; Симеуновић-Патић, 2009; Spaaij, 2005; Stott et al., 2008; Varela, 2014). То су: величина града у којем живе, комплетност породице, материјална ситуација, конзумација алкохола, став према полицији и подношене прекршајне пријаве. Разлози за та неслагања могу се тражити у многим факторима. На пример, у истраживању су у исту групу - велике градске средине - сврстани испитаници из Београда, Новог Сада, Ниша, Крагујевца, Суботице, Смедерева и Новог Пазара (према броју становника). Имајући у виду да Београд има 1,47 пута више становника него свих седам осталих градова заједно, јасна је диспропорција градских средина. Ранија истраживања која су показала да су навијачке групе у већим градским целинама организованије и да имају више чланова спроведена су у градовима који су по популацији уједначенији и који најчешће имају више од милион становника, па је вероватно то разлог због којег је дошло до неслагања. Када је реч о материјалној ситуацији, она је у Србији уопштено гледано релативно лоша, због економске кризе и других фактора који су утицали на земљу у последње две и по деценије, па се условно може говорити о уједначености испитиване популације у том погледу. Нека од обележја нису дала јединствен статистички значајан допринос моделу јер нису везана искључиво за навијачке групе, већ за целокупну популацију. На пример, статистички подаци показују да, у зависности од године, између $30 \%$ и $42 \%$ становништва Србије има поверења у полицију (TNS, 2014). Такав став се уопштено преноси и на младу популацију, па негативан став према полицији не даје јединствен статистички значајан допринос опису адолесцента који је припадник навијачке групе. Такође, конзумирање алкохола представља културолошку одлику на подручју Србије, на шта указује и податак да чак $69 \%$ адолесцената конзумира алкохол (Милојевић и сарадници, 2014). Због тога не треба да чуди што у моделу не постоји конзумација алкохола као битно обележје адолесцентног члана навијачке групе.

Дакле, резултати регресионе анализе указали су на то да би се, са високом поузданошћу, адолесцент који је члан навијачке групе, на основу редоследа вредности вероватноћа датих у Табели 2 и тумачења резултата из Табеле 1 , могао описати као мушкарац који учествује у сукобима због погрешно усмерених навијачких страсти, који злоупотребљава наркотике и против којег је полиција подносила кривичне пријаве након привођења због навијачког насиља. Он не жели да се додатно информише о проблему навијачког насиља и његовим последицама јер сматра да је довољно упознат са тим, али и препознаје расистичке испаде када се десе на спортским борилиштима. 


\section{ЗАКЉУЧАК}

Резултати представљени у раду указују на то да постоје заједничке карактеристике које у својој интеракцији описују адолесценте који се прикључују навијачким групама, што је и почетна претпоставка овог рада. На основу тога, у раду је представљен модел описа адолесцента из навијачке групе, састављен од обележја која су у претходним студијама о навијачком хулиганизму наведена као карактеристична. Тај модел са великом вероватноћом указује на поуздан опис адолесцентног члана навијачке групе.

Представљени опис веома је важан за правилно усмеравање и конципирање превентивних програма. Наиме, представљени резултати указују на то да је 25,3\% испитаника учествовало у неком облику насиља које је мотивисано погрешно усмереним навијачким страстима, док је 14,7\% испитане популације активно у некој од навијачких група. Према томе, хулиганизам и насиље на спортским манифестацијама није карактеристика која је преовлађујућа у адолесцентској популацији. Због тога, превентивни програми усмерени ка сузбијању хулиганизма и насиља у спорту не могу бити конципирани на начин да се њима обухвати целокупна млада популација јер могу изазвати снажно негодовање већинског дела адолесцената који немају везе, нити су заинтересовани за тај проблем. Такви програми морају се циљно усмерити на онај део младих који имају предиспозиције да постану насилни чланови навијачких група. Опис адолесцентног члана навијачке групе који је представљен у раду има управо ту сврху.

Резултати истраживања показали су да је само 2,3\% девојака из испитане популације активно у организованим навијачким групама, док их је 6,5\% учествовало у неком облику насиља које је мотивисано погрешно усмереним навијачким страстима. У складу са тим, превентивни програми усмерени ка сузбијању хулиганизма и насиља у спорту требају се моделовати тако да су примеренији мушкој популацији адолесцената - нпр. рекламне поруке током преноса спортских догађаја, на интернет локацијама и каналима на друштвеним мрежама, онлајн играма и сл., које чешће посећује мушка популација.

Борба против наркоманије и насиља било које врсте међу адолесцентном популацијом стални је задатак целог друштва. При томе, ради очувања подмлатка, а тиме и нације у целини, неопходно је да се при сузбијању наркоманије и насиља међу младима примењује принцип „нулте толеранције”. У програме који су усмерени на борбу против наркоманије и насиља сигурно треба укључити и сегмент превентивних мера усмерених на сузбијање хулиганизма и насиља на спортским приредбама.

Према томе, превентивни програми усмерени ка сузбијању хулиганизма и насиља у спорту требало би да буду усмерени ка малолетној мушкој популацији, најчешће оној која злоупотребљава нар- 
котике, привођеној и процесуираној због навијачког насиља и хулиганизма. Како једна од карактеристика адолесцената из навијачких група јесте да се опиру едукацији као мери превенције, можда треба одустати од класичних облика преношења знања и пронаћи начин да се едукативни садржаји пренесу до њих путем модерне технологије - рачунара, интернета и паметних телефона. Јасно је да се наредни кораци у решавању проблема фудбалског хулиганизма морају заснивати на новим стандардима - од проактивног поступања полиције у супротстављању насиљу на стадионима, па до коришћења модерних технологија као средства за едукацију одређене популације, што може бити предмет неког новог истраживања.

\section{ЛИТЕРАТУРА}

Adang, O., \& Brown, E. (2008). Policing Football in Europe: Politie academie Apeldoorn. Arishita, K. M. (2010). Racism in soccer: Eliminating soccer racism and using sport as a vehicle for national change. Texas A\&M University.

Bošković, A. (2006). Balkan ghosts revisited: Racism, Serbian style. Anthropos, 101(2), 559-564.

Cleland, J., \& Cashmore, E. (2013). Football fans' views of racism in British football. International Review for the Sociology of Sport, 1-17. doi: 10.1177/ 1012690213506585

Đorić, M. (2012). Huliganizam - nasilje i sport [Hooliganism - violence and sport]. Beograd: Udruženje „Nauka i društvo Srbije”.

Earle, R. (2011). Boys' zone stories: Perspectives from a young men's prison. Criminology and Criminal Justice, 11(2), 129-143.

Essays, U. (n.d). A Study On Football Hooliganism Sociology Essay. Retrieved May 09, 2014, from http://www.ukessays.com/essays/sociology/a-study-on-footballhooliganism-sociology-essay.php?cref $=1$.

Hau, S. (2006). Communication as the most important police strategy at the Football World Cup Final 2006.FOG-report.

Janković, B. (2010). Prevention of Violence at Sports Events. Herald of Law, 1(3), $129-154$.

Марковић, С. (2016). Мера безбедности „Забрана присуствовања одређеним спортским приредбама" у пракси полиције и правосуђа [Safety measure "Ban on attendance at certainsporting events" in practice of police and the judiciary]. НБП-Журнал за криминалистику и право, 26(1), 133-160.

Мијалковић, С. (2015). Начионална безбедност [National security]. Београд: Криминалистичко-полицијска академија.

Милашиновић, С., Милојевић, С. и Крстић-Мистриџиловић, И. (2014). Навијачко насиље средњошколаца у Републици Србији [Sports fans violence of secondary school students in the Republic of Serbia]. У зборнику Модели унапређењь безбедности у образовно-васпитним установама [Models for improvement of security in educational institutions] (185-198). Универзитет у Београду, Факултет безбедности.

Milojević, S., \& Janković, B. (2011). Proactive approach of police in combat against football hooliganism. In: Milošević, G. (Ed.):Archibald Reiss Days (737-749). Belgrade: The Academy of Criminalistic and Police Studies. 
Milojević, S., \& Janković, B. (2012). Police measures and actions in confronting football hooliganism in some European countries. In: Milošević, G. (Ed.): Archibald Reiss Days (613-629). Belgrade: The Academy of Criminalistic and Police Studies.

Милојевић, С., Симоновић, Б., Јанковић, Б., Оташевић, Б. и Турањанин, В. (2014). Млади и хулиганизам на спортским приредбама [Youth and hooliganism at sports events]. Београд: ОЕБС, Мисија у Србији.

Милошевић, Г. и Милашиновић, С. (2011). Насиље навијачких група у Србији и криминалитет малолетника [Sport Fans Violence in Serbia and Juvenile Crime]. Теме, 35(2), 495-510.

Милошевић, Н. и Милојевић, С. (2001). Основи методологије безбедносних наука [Basics of the Methodology of the Security Science]. Београд: Полицијска академија.

Мисић, 3. (2010). Насиље и недолично понашање навијача као фактор угрожавања безбедности [Violence and Misbehaviour of Fans as a Factor Compromising Security] (магистарска теза). Универзитет у Београду, Факултет безбедности.

Mostahfezian, M., \& Sarrami, L. (2012). Sociological Survive of Effective Factors on Hooliganism in Football Fans. International Research Journal of Applied and Basic Sciences, 3, 2039-2042.

Оташевић, Б. (2010). Урбано окружење и насиље у спорту [Urban Environment and Violence in Sport]. Безбедност, 52(3), 267-281.

Otašević, B. (2012). Vandals Inside the Walls- Phenomenology of Hooliganism. Безбедност, 54(1), 54-71.

Оташевић, Б., Вла, С. и Исаковић, Г. (2011). Полицијска тактика сузбијања насиља на спортским приредбама [Police Tactics of Supressing Vilence at Sporting Events]. У зборнику Сузбијање криминала у оквиру међународне полицијске capadre [Fighting crime in the framework of international police cooperation] (429-439). Београд: Криминалистичко-полицијска академија.

The Premier League (2008). National Fan Survey, Summary Report 2007/08 Season. London.

Radulović, L. (2010). The role of education in youth crime prevention. Foreign legal life, 1 $(145-169)$.

Roumen, D. (2008). Gender violence, fan activism and public relations in sport: The case of "Footy Fans Against Sexual Assault". Public Relations Review, 34, 90-98. doi: 10.1016/j.pubrev.2008.03.002.

Savković, M., \& Đorđević, S. (2010). Towards the prevention of violent acts at sports events: Proposal on regional cooperation framework. Belgrade Centre for Security Policy.

Симеуновић-Патић, Б. (2009). Криминалитет малолетника у Републици Србији и савремена друштвена реакиија [Juvenile crime in the Republic of Serbia and the contemporary social reaction] (докторска дисертација). Универзитет у Крагујевцу, Правни факултет.

Spaaij, R. (2005). The prevention of football hooliganism: A transnational perspective. In: Aquesolo, J. (Ed.): Actas del X Congreso Internacional de Historia del Deporte (1-10). Seville: CESH.

Statistical Office of the Republic of Serbia (2013). Upper Secondary Education in the Republic of Serbia, Beginning of 2012/2013 School year. Belgrade.

Stott, C., Adang, O., Livingstone, A., \& Schreiber, M. (2008). Tackling football hooliganism: A quantitative study of public order, policing and crowd psychology. Psychology, Public Policy, and Law, 14(2), 115-141. doi: 10.1037/a0013419

TNS Medium Gallup (2014). Stav građana prema radu policije [Attitude of Citizens toward the Work of the Police]. Beograd. 
Varela, S. (2014). Drunk and Proud, from the streets to the stands: America Football Club fans, aguante and alcohol consumption in Mexican football fandom. International Review for the Sociology of Sport, 49, 435-450. doi: 10.1177/1012690213499333

Живковић, М., Стаменковић, Л. и Марковић, М. (2013). Насиље у спорту и његови актери у савременом друштву [Violence in Sport and its Perpetrators in Modern Society]. Теме, 37(2), 939-952.

\title{
DETERMINANT CHARACTERISTICS OF AN ADOLESCENT MEMBER OF A FAN GROUP
}

\author{
Saša Milojević, Saša Mijalković, Bojan Janković \\ The Academy of Criminalistic and Police Studies, Belgrade, Serbia
}

\section{Summary}

In the last decade there has been a noted tendency that adolescents appear more and more often in the role of violent persons on the stands of stadiums. Violent behavior is most often shown in the so called fan groups with a large number of adolescents. This paper aims to answer the question whether there are common characteristics of adolescents who join fan groups.

In order to obtain the data about participation of the youth in violence at football matches and hooliganism of supporters, a questionnaire comprising 13 questions was made. The survey was anonymous. The collected data were processed using methods of statistical analyses, namely the procedures which showed descriptive parameters (frequency and percentage) and regression techniques for examination of the validity of the model of characteristics that describe a minor participant of a fan group.

The data on the participation of the youth in violence at football matches were collected on the sample comprising of secondary school students aged 14 to 19 from the territory of the Republic of Serbia. The respondents were from 12 cities that had first league football clubs in the season 2012/2013 and from two schools located nearest to the football stadium. Four generations of the students from two classes, each, were surveyed in schools. Based on these criteria, 3662 students were surveyed. The sample comprised $14.7 \%$ of members of organized fan groups.

The collected data analysis showed that there are common characteristics of adolescents who join a fan group, the phase of which they significantly differ from the remaining part of the population of adolescents, which is actually the starting point of this paper. Based on these characteristics, a young member of a fan group can be described as an adolescent who participates in conflicts because of football, who is apprehended by the police and against whom criminal charges because of violence at football matches are filed. He does not want to be educated about the problem of football hooliganism because he thinks he is familiar with it, and recognizes racist incidents in stadiums as its integral part. He has consumed illegal opiates. The presented description is very important for a proper routing of prevention programmes aimed at reducing violence in stadiums.

As the characteristic of adolescents who are members of fan groups is to oppose education as a measure of prevention, we should abandon the classical forms of knowledge transfer and find a way to introduce educational contents with modern technology computers, the Internet and smartphones. 